\title{
Chemokine (C-X-C Motif) Ligand 3 Measurement
}

National Cancer Institute

\section{Source}

National Cancer Institute. Chemokine (C-X-C Motif) Ligand 3 Measurement. NCI

Thesaurus. Code C147329.

The determination of the amount of chemokine (C-X-C motif) lig and 3 present in a sample. 